sis; however, we believe that the fistula was secondary to a progressive infected aortic aneurysm around the endograft rather than the initial source of the patient's fatal condition. First, the aortoesophageal fistula appeared months after the endograft was performed, whereas dysphagia or hematemesis occurred early in the course of treatment. ${ }^{1,2}$ Our patient received an endograft for aortic aneurysm 7 years before presentation; he had no hematemesis or dysphagia until the 20th hospital day. Second, his esophagus was well visualized on initial computed tomography, and there was no indication of abnormal soft tissue around the esophagus or in the esophageal wall, findings that are important for the diagnosis of aortoesophageal fistula. ${ }^{1,3}$ We intended to highlight the critical aortic infection, especially its manifestation on chest radiography. According to the patient's clinical features and the imaging findings, his septicemia was the most likely cause of the gaseous, infected aneurysm.

Yi-Luan Huang, M.D.

Ming-Ting Wu, M.D.

Kaohsiung Veterans General Hospital

Kaohsiung, Taiwan

wu.mingting@gmail.com

Since publication of their article, the authors report no further potential conflict of interest.

1. Eggebrecht H, Mehta RH, Dechene A, et al. Aortoesophageal fistula after thoracic aortic stent-graft placement: a rare but catastrophic complication of a novel emerging technique. JACC Cardiovasc Interv 2009;2:570-6.

2. Cernohorsky P, Reijnen MM, Tielliu IF, van Sterkenburg SM, van den Dungen JJ, Zeebregts CJ. The relevance of aortic endograft prosthetic infection. J Vasc Surg 2011;54:327-33.

3. Chiba D, Hanabata N, Araki Y, et al. Aortoesophageal fistula after thoracic endovascular aortic repair diagnosed and followed with endoscopy. Intern Med 2013;52:451-5.

DOI: 10.1056/NEJMc1403841

\title{
Physician Attitudes and Experience with Permit Applications for Concealed Weapons
}

TO THE EDITOR: Every U.S. state allows people to carry concealed weapons within certain limits and after varied approval processes. ${ }^{1,2}$ Although many states require physician participation to help determine competency, it is not known whether physicians are capable of assessing a patient's competence to carry a concealed weapon. ${ }^{3}$

We designed a survey to assess physician attitudes, beliefs, and behaviors with regard to concealed weapons. Physician attitudes were assessed on the basis of itemized responses to questions in four categories; their answers ranged from "strongly agree" to "strongly disagree." Respondents disclosed information on demographics, practice type, and gun ownership. The survey was sent by mail to 600 physicians registered with the North Carolina Medical Board who were in active practice in October 2013.

Of the 600 surveys sent, 45 were returned uncompleted and 222 were returned completed (adjusted response rate, $40 \%$ ). The majority of respondents were male (66\%), had been in practice for more than 15 years (64\%), and saw at least 10 patients a day (77\%). Approximately one third of respondents $(35 \%)$ were family physicians; $38 \%$ were psychiatrists and $27 \%$ were internists. Eighty physicians (36\%) indicated that they owned a gun.
Among the 222 respondents, $21 \%$ stated that they had been asked to sign competency permits for concealed weapons in the previous year, and the majority of those asked had been requested to sign off on more than three such permits. Among the physicians who were asked to sign competency permits, most (79\%) agreed to certify competency. The majority of physicians felt that they could not assess their patients' physical capability to carry concealed weapons, and a sizable minority did not feel comfortable assessing mental capability to carry concealed weapons (Table 1). Physicians' beliefs about their capability to assess the physical competence of patients to carry concealed weapons were not significantly related to their actual signing of those permits. Most physicians (84\%) also felt that medical assessments for competency should be conducted by physicians specifically trained in making such assessments.

Physician responses to our survey reveal concern about the suitability of many physicians to make recommendations regarding competence to carry a concealed weapon. A majority of physicians were also worried about the potential ethical consequences of participation in this assessment for the doctor-patient relationship. Policymakers may use these data to reexamine 


\begin{tabular}{|c|c|c|c|c|}
\hline \multirow[t]{3}{*}{ Statement } & \multicolumn{4}{|c|}{ Survey Respondents $(\mathrm{N}=\mathbf{2 2 2})$} \\
\hline & $\begin{array}{l}\text { Strongly } \\
\text { Agree }\end{array}$ & Agree & Disagree & $\begin{array}{l}\text { Strongly } \\
\text { Disagree }\end{array}$ \\
\hline & \multicolumn{4}{|c|}{ number (percent) } \\
\hline $\begin{array}{l}\text { I am knowledgeable about state and federal laws on } \\
\text { concealed weapons and permits }\end{array}$ & $29(13)$ & $61(27)$ & $106(48)$ & $27(12)$ \\
\hline $\begin{array}{l}\text { I can adequately assess whether my patient is physically } \\
\text { capable of safely using a concealed weapon }\end{array}$ & $22(10)$ & $69(31)$ & $104(47)$ & $27(12)$ \\
\hline $\begin{array}{l}\text { I can adequately assess whether my patient is mentally } \\
\text { capable of safely using a concealed weapon }\end{array}$ & $27(12)$ & $91(41)$ & $82(37)$ & $21(10)$ \\
\hline $\begin{array}{l}\text { It is the role of primary care physicians to assess whether } \\
\text { their patients are mentally and physically sound enough } \\
\text { to carry a concealed weapon }\end{array}$ & $10(5)$ & $62(28)$ & $92(41)$ & $53(24)$ \\
\hline $\begin{array}{l}\text { I worry that refusing to sign a statement that my patient is } \\
\text { mentally and physically fit to carry a concealed weapon } \\
\text { may cause problems in the doctor-patient relationship }\end{array}$ & $26(12)$ & $104(47)$ & $69(31)$ & $16(7)$ \\
\hline $\begin{array}{l}\text { Medical assessments for patients applying for concealed } \\
\text { weapon permits should be performed by physicians with } \\
\text { specific training in making such assessments }\end{array}$ & $95(43)$ & $89(41)$ & $25(11)$ & $10(5)$ \\
\hline
\end{tabular}

the current role of physicians in the concealedweapons permitting process. More research is also needed to determine whether the experiences and opinions of physicians from other states differ from those of physicians in North Carolina.

\section{John Pierson, B.S.}

Anthony J. Viera, M.D., M.P.H.

Kathy K. Barnhouse, M.D.

University of North Carolina School of Medicine Chapel Hill, NC

James A. Tulsky, M.D.

Barak D. Richman, J.D., Ph.D.

Duke University

Durham, NC

\section{Adam O. Goldstein, M.D., M.P.H.}

University of North Carolina School of Medicine

Chapel Hill, NC

Supported by funds provided by the University of North Carolina School of Medicine, Department of Family Medicine.

Disclosure forms provided by the authors are available with the full text of this letter at NEJM.org.

1. Gun control: states' laws and requirements for concealed carry permits vary across the nation. Washington, DC: Government Accountability Office, 2012. (Report no. GAO-12-717.) 2. Jones A. Illinois abolishes ban on carrying concealed weapons. Wall Street Journal. July 9, 2013 (http://online.wsj.com/ news/articles/SB10001424127887324867904578596150074731668). 3. Goldstein AO, Barnhouse KK, Viera AJ, Tulsky JA, Richman BD. Assessing competency for concealed-weapons permits - the physician's role. N Engl J Med 2013;368:2251-3.

DOI: 10.1056/NEJMc1401815

Correspondence Copyright (c) 2014 Massachusetts Medical Society.

\section{NOTICES}

Notices submitted for publication should contain a mailing address and telephone number of a contact person or department. We regret that we are unable to publish all notices received. Notices also appear on the Journal's website (NEJM.org/medical-conference). The listings can be viewed in their entirety or filtered by specialty, location, or month.

\section{IITH ANNUAL CONNECTED HEALTH SYMPOSIUM}

The symposium, entitled "Connected Health in Practice: Engaging Patients and Providers Outside of Traditional Care Settings," will be held in Boston, Oct. 23 and 24. It is presented by Partners HealthCare.

Contact the Center for Connected Health, 25 New Chardon St., \#300, Boston, MA 02114; or call (617) 643-7976; or fax (617) 228-4626; or e-mail PHSConnectedHealthSymposium@ partners.org; or see http://symposium.connected-health.org.

\section{SOCIETY OF LAPAROENDOSCOPIC SURGEONS}

The following meeting will be held: "Minimally Invasive Surgery Week 2014: Annual Meeting and Endo Expo" (Las Vegas, Sept. 10-13).

Contact the Society of Laparoendoscopic Surgeons, 7330 SW 62nd Place, Suite 410, Miami, FL 33143; or call (305) 665-9959; or fax (305) 667-4123; or see http://www.sls.org.

THE JOURNAL'S WEB AND E-MAIL ADDRESSES
To submit a letter to the Editor: authors.NEJM.org
For information about the status of a submitted manuscript:
authors.NEJM.org
To submit a meeting notice: meetingnotices@NEJM.org
The Journal's web pages: NEJM.org

